\title{
ADVANCED TECHNICAL WRITING: THE STUDENT AS INVESTIGATOR
}

\author{
Lilita Rodman
}

\section{INTRODUCTION}

UBC offers two thirteen-week courses in technical writing (or 'practical' writing, as we call it). The introductory course centres on a recommendation report and enrols some eight hundred students annually; the advanced one focuses on a library research essay and the analys is of journal articles and enrols about fifty students. For the last three years I have begun the advanced course with an assignment that requires the student to locate an established practitioner of the profession the student plans to enter, to interview this person about his/her professional writing, and then to present the results in a memo to me and an oral report to the class.

This assignment has at least the following advantages:

1) It contributes directly to the students' understanding of writing in their particular professions. They meet someone who is doing the kind of work for which they are training; they usually see the environment in which it is done; they learn about the kinds of writing products that are required and the writing processes one writer uses; and they hear this writer's comments about the importance of writing. Most of this we cannot provide in class, not only because we draw students from a wide variety of disciplines, but more importantly because we simply don't have much access to this kind of information.

2) It provides a real, not a simulated, purpose and audience. The students know that I do, indeed, want to learn about writing in the various disciplines. As well, they know that the class wants to learn from the oral reports.

3) It provides practice in conducting an investigation and reporting results.

4) It combines practice in oral and written communication. In addition to writing a suitable memo report, the student must arrange the interview, conduct it, and report orally to the class.

5) It provides a review and overview of the work of the introductory course. 
6) It provides the instructor with useful information. Reading more than sixty of these assignments in the last three years has taught me quite a bit about writing in the workplace. Later in the paper I will outline some of the more interesting results.

\section{THE ASSIGNMENT}

\section{Locating the Informant}

Because the informant must be someone who writes, and because the more complex and varied the informant's writing is, the more interesting will a student's report be, I suggest students choose someone who has been out of university for at least five years. Table 1 gives the experience distribution for 31 informants:

\section{TABLE 1}

\section{EXPERIENCE OF RESPONDENTS}

\begin{tabular}{|c|c|}
\hline $\begin{array}{c}\text { Years in } \\
\text { Profession }\end{array}$ & $\begin{array}{c}\text { Number of } \\
\text { Respondents }\end{array}$ \\
\hline $30+$ & 4 \\
$25-29$ & 3 \\
$20-24$ & 2 \\
$15-19$ & 6 \\
$10-14$ & 6 \\
$5-9$ & 8 \\
$0-4$ & 2 \\
\hline
\end{tabular}

Some students already know a suitable informant among family friends or from summer jobs, while others have to rely on the telephone book or leads from their classmates or professors. In the first two years I also accepted professors as informants, but now I don't because their writing requirements are generally too dissimilar from those in industry.

The main problems in this step are procrastination in locating an informant and difficulties in arranging a convenient time for the interview, which typicaliy lasts from half an hour to an hour.

\section{Preparing a Questionnaire}

The success of the assignment depends in large part on adequate class preparation for the interview. At first I overestimated the 
students' ability to construct an appropriate questionnaire. Now I think that while the potential questions are best elicited from students, the instructor must also ensure that the most important questions are, indeed, included. I begin by suggesting the following broad questions:

1. How important is writing in this profession?

2. What kinds and quantities of writing does the informant produce?

3. What are the conditions under which the informant writes?

4. What are the informant's usual writing processes?

5. What kinds of writing does the informant read as part of his/her work?

We then discuss more detailed questions that should be included in the interview; Appendix A lists some of these. This list could, of course, be expanded on the basis of some of the formal studies of writing in non-academic settings; but at the same time as I would stress the importance of giving students rather specific guidelines, I would caution against too rigorous and too uniform an approach, mainly because to turn this assignment into the basis for a statistical study could detract from the 'anecdotal' quality of the reports and also probably limit some of the serendipitous comments and information that a less structured approach elicits. It is more important, I think, for the students to get a sense of the breadth and variety of the writing situations in their professions than it is for an instructor to get readily processable data. Also, keeping the questionnaire somewhat open challenges the student to add or expand questions.

\section{The Memo Report}

The memo affords ample opportunity to use headings and to determine how to present numerical and anecdotal information effectively. The main difficulty is organization, for the data tend to present awkward problems of cross-classification.

\section{Oral Report}

The oral reports and the brief question periods after each allow the class to discuss the results. Perhaps the outstanding qualities of these sessions are enthusiasm and interest--mine as well as the students $^{1}$. Often the report begins with a brief description of the workplace, which, particularly if the informant is a fairly senior professional, can provide an entertaining impression of "life at the top.' 
RESULTS

Although the assignment is designed primarily for the students' benefit, it does, of course, provide data about writing in the professions. While I will present some results as percentages, it is very important to recognize that I am not claiming statistical accuracy; the sample is small, skewed, and too heterogeneous, and the investigative instrument is too variable.

\section{Importance of Writing}

The responses to this question are probably most affected by the skewed sample. The informants have been pre-selected because they are required to write as part of their work and they all share the kind of attitude to writing and perhaps their own writing that would lead them to agree to be interviewed about it. The data on the portion of working time spent writing are presented in Table 2:

TABLE 2

TIME SPENT WRITING

\begin{tabular}{|c|c|c|}
\hline $\begin{array}{c}\text { \% of Time } \\
\text { Spent Writing }\end{array}$ & $\begin{array}{c}\text { Number of } \\
\text { Respondents }\end{array}$ & $\begin{array}{c}\% \text { of } \\
\text { Respondents }\end{array}$ \\
\hline $75-100$ & 5 & 24 \\
$50-74$ & 6 & 29 \\
$25-49$ & 3 & 14 \\
$0-24$ & 7 & 33 \\
\cline { 2 - 3 } & 21 & 100 \\
\hline
\end{tabular}

In other words, more than half of those informants for whom I have results indicate they spend more than half their time writing. Four of the five who spend $75 \%$ or more of their time writing have spent 10 years or less in their profession and all five work in consulting or research. These results are somewhat higher than the means reported by Erickson 1 for technicians $(24.5 \%)$, Davis 2 for established engineers (24.35\%), and Anderson ${ }^{3}$ for junior professionals $(30 \%)$, and similar to Selzer's 4 results for one established engineer (50\%).

The infomants' comments complement the statistics given above:

1. "The success of an out-of-court lawyer depends almost entirely on writing and editing skills." 
2. "Writing in itself cannot cause upward mobility in the corporation; however, lack of writing ability would not be tolerated." (Industrial Relations Lawyer)

3. "Writing skills are perhaps the single most important factor governing promotability." (Civil Engineer)

4. "Writing skills are as important as technical skills. Accounting students without good writing skills are assured of being dropped by the firm within two years unless their technical skills are exceptional. A person lacking writing skills is useless to the firm."

Even though the students show by their registration in this elective course that they have accepted the importance of writing, their oral reports generally indicate surprise at how important writing can be.

\section{Kinds and Quantities}

Unfortunately the variability of response to this question precludes quantification. All informants report having to do a great variety of kinds of writing, not just in terms of form, but also in terms of purpose and audience. Several stress the relationship between the stages of a project and the kinds of writing required; this dependence is perhaps best summarized in a report on an architect's writing (see Appendix $B$ ). All informants also report writing some letters, with six claiming to write twenty or more a week. This result echoes Bataille's conclusion that "letters are important to all groups" 5 in his multi-disciplined sample of graduates; his informants report spending $21 \%$ of their time writing letters.

\section{Writing Conditions}

Writing in the workplace seems to be governed by tight deadlines, frequent interruptions, and the fact that any document can have legal implications. While our classrooms can't, of course, duplicate the work environment, I think we should recognize how different the classroom is from the office, and consider the paedagogic implications of this difference. For example, perhaps we do students a disservice by stressing careful planning and revision of all assignments. Should we also be concerned with developing the ability to write tolerably in very limited time with frequent interruptions?

\section{Writing Process}

While all respondents report some differences in how they approach different writing tasks, the most common procedure seems to be to write 
or dictate a draft which a secretary types or enters in a word processor and which is then proofread. Of the twenty-five who mention a medium for composing, $40 \%$ specify handwriting only, $38 \%$ mention using a dictaphone at least for shorter documents, and only $14 \%$ claim to compose on a word processor. The dictaphone is used most by those whose professions have a clear business emphasis and who have more than ten years' experience. The reason given for using the dictaphone is efficiency. An accountant, for example, claims that he can dictate a two-paye document in three minutes, and says that he sometimes dictates over the telephone. An engineering manager, whose concern with efficiency seemed a bit extreme, dictates while driving; he claims that $80 \%$ of this dictation goes as final copy. While the popularity of the dictaphone may only reflect this sample's age, perhaps we should pay some attention to training students to dictate short documents.

Although it is very difficult, of course, to decide exactly what the informants mean by a draft or by proofreading, editing, and revising, the amount of revising does appear to vary with the length of the document and with its importance. This variability is also reported by Mair and Roundy. 6 Table 3 presents the responses to how many drafts are used:

TABLE 3

NUMBER OF DRAFTS

\begin{tabular}{|c|c|c|}
\hline $\begin{array}{c}\text { Number of } \\
\text { Drafts }\end{array}$ & $\begin{array}{c}\text { Number of } \\
\text { Respondents }\end{array}$ & $\begin{array}{c}\text { \% of } \\
\text { Respondents }\end{array}$ \\
\hline 1 & 4 & 18 \\
2 & 8 & 36 \\
$3+$ & 10 & 46 \\
\cline { 2 - 3 } & 22 & 100 \\
\hline
\end{tabular}

All four who report doing no revising use dictaphones. The eight who report using two drafts all speak of proofreading, not revising; spend less than half of their time writing; and tend to write shorter documents. As well, two of them are among those who use a dictaphone. The largest numbers of drafts are mentioned by the professors in the sample and usually they are referring to writing articles for publication. Again, I think, this may emphasize the difference between writing we habitually engage in and the writing our students will have to do.

The reported comments about drafts are also interesting, I think. One lawyer says, "Nobody can write a good document in less (sic) than three drafts," and that he revises "until the cost of further revising is not justified." On the other hand, a banker says, "If you set out to write a draft, all that you will accomplish is a draft." Although most of us would probably side with the lawyer, there is probably some truth 
to the banker's comment, particularly with respect to shorter documents. Group or collaborative writing is mentioned by ten informants, but only in the context of writing books, pamphlets, and long reports. Several of these mention group meetings to discuss outlines.

\section{CONCLUSION}

I think this assignment is useful in bridging the gap between the classroom and the workplace, both for the student and for the instructor, and although I would not wish merely to make students into fieldworkers, I think that their reports can be a very useful source of anecdotal evidence about writing in the professions. Although I've used this assignment at the beginning of an advanced course, I think it could as well be used near the end of an introductory course.

\section{REFERENCES}

1Harold P. Erickson, "English Skills Among Technicians in Industry," Technical Education News 28(Jan./Feb. 1969): 16-18.

2Richard M. Davis, "How Important is Technical Writing?--A Survey of the Opinions of Successful Engineers," The Technical Writing Teacher (Spring 1977). Reprinted in Journal of Technical Writing and Communication 8.3 (1978): 207-16.

${ }^{3}$ Paul Anderson, "Research into the Amount, Importance, and Kinds of Writing Performed on the Job by Graduates of Seven University Departments that Send Students to Technical Writing Courses," paper presented at Conference on College Composition and Communication, Dallas, 1981.

4Jack Selzer, "The Composing Processes of an Engineer," College Composition and Communication 34 (1983): 178-87.

5 Robert R. Bataille, "Writing in the World of Work: What Our Graduates Report," College Composition and Communication 33 (1982): 277.

6David Mair and Nancy Roundy, "The Composing Process of Technical Writers: A Preliminary Study," Technical Communication: Perspectives for the Eighties, NASA Conference Publication 2203, Part 2, p. 544.

Lilita Rodman has taught technical and business writing in the Department of English at the University of British Columbia since 1969. She is particularly interested in style in technical writing and the use of graphics in technical discourse. 
APPENDIX A

\section{SUGGESTED QUESTIONS}

A. INFORMANT--name, position, brief career history, education

B. IMPORTANCE OF WRITING

What portion of his/her working time does the informant spend writing?

How important is writing to success in this profession?

What advice does the informant have for students?

C. KINDS OF WRITING

- determine what writing forms are required (e.g., letters, memos, reports, articles, other)

- for each kind determine length, frequency, purpose, audience

D. WRITING CONDITIONS

How is work initiated?--i.e., is it assigned?

How much time is available for preparing a document?

How tightly must deadlines be observed?

Is most of the writing done at work or at home?

Is group writing done?

How many drafts are usually needed?

Is a word processor used?

E. WRITING THAT IS READ

What kinds of writing cross the desk? 
APPENDIX B

\section{EXCERPT FROM REPORT ON ARCHITECT}

The kind and quantity of writing required from an architect varies with the stages of the project, the part or parts of the project the architect is involved in, and the nature of the project itself. In the first stage of a project, Ms. Monsson writes brief, explanatory letters to the client and ensures that the client approves of her ideas and understands what she is doing. In the next stage, when construction is underway, Ms. Monsson may need to write only occasionally. One such occasion would be if she disagrees with the way in which something in a project she is working on is being built. Then she will write to the contractor; in a letter she will very clearly explain why she disagrees. Another such occasion would be if the project is large and will take a long time to complete. Then the client or Mr. Negrin may desire progress reports, which are done in point form about every two weeks and, in general, are not long. In the final stage of the project, when construction is complete, Ms. Monsson will confirm, in writing, that the client is satisfied. So, as the project continues, various writing is required. The most writing is necessary at the initial stage of most projects and is almost exclusively letters to the client. However, depending on the part of the job assigned, the architect may do more and different kinds of writing at different stages. For example, when Ms. Monsson was supervising the renovations to the Pallister Hotel, she was required to attend and write minutes at construction meetings. This also involved ensuring that the contractor's minutes coincided with her own, and if they did not, she had to clarify with the contractor what the discrepancy was. Because of her assignment in this project, Ms. Monsson did more writing in the second stage of the project than she did in the first stage. Then there are projects in which Ms. Monsson is not directly involved, but for which she is required to write a critique of a mechanical or electrical system. In such a case, she writes the critique to the extent of her knowledge; that is, she does little research on anything other than the specific system being analysed. At other times, Mr. Negrin may ask Ms. Monsson to do a summary of a contractor's report. Thus, as the projects progress and change, the writing required from the architect necessarily fluctuates in quantity and varies in form. 